Anna Wróblewska (iD http://orcid.org/0000-0002-3302-4055

Wydział Organizacji Sztuki Filmowej

Państwowa Wyższa Szkoła Filmowa, Telewizyjna i Teatralna w Łodzi

e-mail: annadorotawroblewska@gmail.com

\title{
Zrównoważona produkcja filmowa w Polsce. Geneza i perspektywy
}

Abstract

\section{Sustainable Film Production in Poland. The Origin and Prospects}

The 21st century has seen a growing awareness of the serious impact of film and television production on the natural environment. The film industry pollutes our environment in many ways, including carbon dioxide emissions, waste production, and energy and water consumption. The initiatives for sustainable development undertaken in many sectors of the economy have also reached the film industry. In Europe and the United States, various organisations and institutions have developed a number of recommendations in the field of sustainable film production. This paper, set in the film studies trend known as production culture, presents the global context as well as the nascent Polish practices of green filming. These initiatives, based on European examples, have so far been mainly bottom-up and dispersed or in the form of non-binding recommendations. The handful of producers and authors who have undertaken them are not in any way encouraged to be eco-friendly. Driven by their concern for the environment, however, they show the forward-looking way of thinking that should be followed by the entire industry.

Keywords: sustainable film production, green filming, production culture

Słowa kluczowe: zrównoważona produkcja filmowa, zielona produkcja filmowa, kultura produkcji 


\section{Nprowadzenie}

Oddziaływanie przemysłu filmowego na otoczenie może być ujmowane bardzo szeroko: w kontekście kulturowym, gospodarczym, regionalnym, a także, jak w ostatnich latach, w kategoriach wpływu na środowisko naturalne. Dane liczbowe zebrane w ramach finansowanego przez Interreg Europe projektu „Green Screen”, partnerstwa obejmującego osiem regionów UE, w tym Polskę, ilustrują poziom wpływu filmu lub programu telewizyjnego na środowisko. Produkcja audiowizualna emituje od 50 do 3500 ton dwutlenku węgla, w zależności od wielkości i budżetu danego projektu [Rzeszowska Agencja Rozwoju Regionalnego 2020]. Według organizacji Sustainable Production Alliance średnia wielkość „śladu węglowego” filmów to 3370 ton ekwiwalentu dwutlenku węgla - około 33 ton na dzień zdjęciowy [Sustainable Production Alliance 2021, s. 2]. Film o budżecie ponad $70 \mathrm{mln}$ USD wytwarza 2840 ton dwutlenku węgla. Przemysł filmowy wywiera wpływ na środowisko w wielu obszarach, z których najważniejsze to: transport i zakwaterowanie, gospodarka odpadami, materiały, wyżywienie i zużycie energii [Albert 2020, s. 6-12].

Rdzeniem przemysłu filmowego jest produkcja (filmów, seriali, powiązanych form audiowizualnych). Niezależnie od tego, czy widz obejrzy film w kinie, czy w serwisie VOD i czy film powstaje z wykorzystaniem środków publicznych, czy bez nich, pozostaje produktem wytworzonym w celu osiągnięcia przychodu. Tematem niniejszego artykułu jest implementacja idei zrównoważonej produkcji w obszarze kinematografii, w tym działań podejmowanych w Polsce. Podstawowe cechy zrównoważonej produkcji zawarte są w czterech obszarach: wielkość produkcji, asortyment produktów, procesy technologiczne, postawy i zachowania pracowników. Funkcjonowanie tych obszarów oparte jest na wielu nowych ideach, które są przeciwstawne dotychczasowym praktykom w biznesie i schematom myślowym. Jednym z wyzwań jest przekształcenie przedsiębiorstw w zrównoważone organizacje. W zrównoważonym przedsiębiorstwie zasoby, działalność i wytwory podporządkowane są zasadzie sustainability. Oznacza ona rozwój w kierunku zaspokajania potrzeb ludzkich bez nadmiernego wykorzystania zasobów środowiska naturalnego i czynienia szkody kolejnym pokoleniom [Pabian 2017, s. 365-374].

Kluczowymi pojęciami w niniejszym artykule są: zielona produkcja filmowa oraz zrównoważona produkcja filmowa, które są kalkami angielskich określeń: green filmmaking lub green filming i sustainable film production. W Polsce obu określeń używa się wymiennie, choć krajowe instytucje (np. Krajowa Izba Producentów Audiowizualnych czy Łódź Film Commission) w przywołanych poniżej opracowaniach używają także oryginalnego określenia green filming.

W tekście tym przytoczone są współczesne europejskie standardy wdrażania idei zrównoważonej produkcji w branży filmowej, a także pionierskie polskie doświadczenia w tym zakresie. Celem artykułu jest ukazanie procesu wdrażania idei zrównoważonej produkcji filmowej na polskim gruncie. W jakim stopniu są to 
działania strategiczne związane $\mathrm{z}$ dalekosiężną polityką przedsiębiorstw i branży, a w jakim oddolne inicjatywy czy wręcz efemeryczne mody? Kim są inicjatorzy zielonej produkcji filmowej w Polsce? W jaki sposób modyfikują przytoczone w tekście standardy wprowadzone w krajach Europy Zachodniej? Na obecnym etapie, bez wyraźnego systemowego, instytucjonalnego wsparcia, zrównoważona produkcja filmowa jest kolejnym wyzwaniem, z jakim muszą zmierzyć się producenci i członkowie ekip filmowych. W polskim kontekście mówimy tu o bardzo nowym, wciąż kształtującym się trendzie. Zainteresowanie zrównoważoną produkcją filmową na świecie wzrastało nieprzerwanie w ciągu ubiegłej dekady. W Polsce pierwsze dyskusje na ten temat, a także kodeksy dobrych praktyk dostosowane do rodzimych realiów pojawiły się dopiero w 2019 roku. Artykuł jedynie zarysowuje temat, gdyż w moim przekonaniu jest obecnie zdecydowanie za wcześnie, by przeprowadzić wiarygodne bardziej szczegółowe badania wśród producentów filmowych, zwłaszcza w sytuacji, kiedy wyzwania i koszty związane z organizacją pracy filmowej w warunkach pandemii COVID-19 przesunęły punkt ciężkości z dyskusji środowiskowej w stronę nowych pól eksploatacji, a także wyzwań związanych z bezpieczeństwem pracy i ochroną pracowników.

Mniej więcej od 2014 roku z pewną regularnością pojawiają się naukowe ujęcia problemu, zwracające uwagę na poszczególne jego aspekty. Jest ich wciąż jeszcze stosunkowo niewiele. Znacznie bogatszy jest wybór raportów i opracowań branżowych na temat praktyk ekologicznych, które ukazują się już od pierwszej dekady XXI wieku. Niektóre $\mathrm{z}$ tych raportów oraz artykuły naukowe zostały przywołane w niniejszym artykule. Jedno z pierwszych opracowań ukazało się w Los Angeles już w 2005 roku, między innymi z inicjatywy gubernatora Kalifornii, byłego gwiazdora filmów akcji Arnolda Schwarzeneggera. Badania, jakie podjął uniwersytet w Los Angeles, miały na celu zidentyfikowanie najlepszych praktyk w zakresie ochrony środowiska w branży filmowej, a następnie opracowanie przewodnika ekologicznej produkcji. Raport UCLA zawiera oszacowanie wpływu przemysłu filmowego na środowisko regionu Los Angeles, a także wiele przykładów najlepszych praktyk na rzecz ochrony środowiska [UCLA 2006]. Z kilkudziesięciu dostępnych online opracowań przygotowanych przez instytucje działające w branży filmowej na poziomie krajowym lub międzynarodowym zostały wybrane te, które stanowią interesujący kontekst dla polskiej sytuacji. W skali europejskiej najbardziej zaawansowane praktyki i systemy wsparcia zielonej produkcji filmowej pochodzą z Wielkiej Brytanii. Cennym źródłem odniesienia są pierwsze polskie kodeksy „zielonych” praktyk, dostosowane do rodzimych realiów.

Zebrane tu fakty, działania oraz inicjatywy zostały przedstawione w publicznych wypowiedziach profesjonalistów z branży filmowej oraz w opracowaniach przygotowanych przez instytucje i organizacje w latach 2020-2021. W tym okresie obserwowałam przenikanie tych inicjatyw z otoczenia europejskiego na polski grunt oraz uczestniczyłam zarówno w sposób czynny, jak i bierny w dotyczących ich 
debatach. W 2020 roku, podczas dwóch ważnych krajowych festiwali filmowych 45. Festiwalu Polskich Filmów Fabularnych w Gdyni i 39. Koszalińskiego Festiwalu Debiutów Filmowych „Młodzi i Film” - zorganizowane zostały publiczne dyskusje na temat zrównoważonej produkcji filmowej. Głosy profesjonalistów przytoczone w tym tekście mają szczególne znaczenie, gdyż należą oni do wąskiego grona osób zaangażowanych w upowszechnianie idei green filming w Polsce.

Prezentowane ujęcie sytuuje zagadnienie zrównoważonej produkcji w obszarze zarówno zarządzania w kulturze, jak i filmoznawstwa, a w szczególności jego nurtu zwanego kulturą produkcji. Waga problemu, związanego z jednym z najważniejszych wyzwań XXI wieku, jakim jest zapobieganie katastrofie klimatycznej, skłania do uważnego przyjrzenia się idei zrównoważonego rozwoju w branży audiowizualnej, a w szczególności w branży filmowej.

\section{W stronę zielonej produkcji filmowej - między sceptycyzmem a realizmem}

Już w 2000 roku w przełomowej monografii Green screen. Environmentalism and Hollywood cinema David Ingram [2000] zauważa ogrom ekologicznej hipokryzji, jaką przejawiają wielkie hollywoodzkie studia. Kino hollywoodzkie utrwaliło romantyczny stosunek do natury i odegrało ważną ideologiczną rolę w tzw. greenwashingu, rozumianym jako „zielone mydlenie oczu” czy „zielone kłamstwo”, tj. wyrażaniu pozornej troski o ochronę środowiska naturalnego przez sektor komercyjny w ramach dyskursów ekologicznych. Sposób angażowania się Hollywood w kwestie środowiskowe zawsze mieścił się w specyficznej dla niego konwencji melodramatu, z gruntu antropocentrycznej. Dlatego w artykułach czy opracowaniach poświęconych zielonej produkcji filmowej wyraźne jest realistyczne i pragmatyczne, a czasem też krytyczne podejście do tej idei. Ekin Gündüz Özdemirci [2016, s. 9-10], przyglądając się praktykom zrównoważonego rozwoju w brytyjskim przemyśle filmowym, zwrócił uwagę na ogromne trudności w trwałym i efektywnym wdrażaniu idei zielonej produkcji filmowej w skali globalnej. Czy zasady zrównoważonego rozwoju są wdrażane na wszystkich etapach realizacji filmu - od prac wstępnych i okresu przygotowawczego poprzez produkcję i postprodukcję aż po dystrybucję, czyli organizację pokazów, wydarzeń, wytwórstwo powiązanych produktów i globalny marketing? Obecny model globalnego przemysłu filmowego, polegający na czerpaniu zysków z najbardziej popularnych produkcji (hitów) oraz z globalnych sieci dystrybucji i merchandisingu, a także międzynarodowych festiwali, nie sprzyja wdrażaniu idei zrównoważonego rozwoju. Im większa produkcja, tym bardziej widoczny jest jej negatywny wpływ na środowisku. Zielona produkcja filmowa może stać się w tym przypadku, zwraca uwagę Özdemirci, zręczną praktyką marketingową, pokrywającą „brudną” rzeczywistość. 
Rozwój zrównoważonego myślenia o produkcji filmowej uzależniony jest od rozwiązania problemów, jakie powoduje specyfika pracy w branży. A problemy te stwarzają zarówno ogólna struktura branży filmowej i organizacja pracy w jej ramach, jak i szczegółowe czynniki, takie jak: napięte harmonogramy, konieczność maksymalizowania wydajności, niespodziewane zmiany organizacji zdjęć. Aby idea zrównoważonej produkcji filmowej mogła być wdrożona w sposób efektywny, konieczne są bardzo głębokie, fundamentalne zmiany funkcjonowania branży przy jednoczesnym, jak zakłada Özdemirci [2016, s. 10-11], wsparciu ze strony państwa w postaci motywujących przepisów. Przeszkodą we wdrażaniu zielonego podejścia w przemyśle audiowizualnym, jak i w każdym innym, jest też niska świadomość pracowników branży w zakresie (negatywnego) wpływu własnych działań na środowisko. Dlatego tak ważne są działania mające na celu podnoszenie świadomości ekologicznej zarówno w branży, jak i wśród odbiorców jej wytworów. Bez względu na to, jak duże będą inwestycje $\mathrm{w}$ „zielone” rozwiązania, czy i o ile zredukujemy odpady na planie i jak mocno wdrożymy zasadę recyklingu, przemysł filmowy będzie miał poważny wpływ na środowisko - tak długo, jak długo będzie kontynuować przyjęty obecnie agresywny model biznesowy.

Poszerzające podejście do tematu prezentuje monografia Streaming media's environmental impact [Marks et al. 2020]. Zwraca uwagę na niepopularny, ale nieunikniony problem niekorzystnego wpływu mediów strumieniowych (czyli działających na zasadzie jednoczesnego przesyłania i odbioru danych audio i wideo za pomocą sieci komputerowej) na środowisko. Coraz więcej ludzi na całym świecie przesyła coraz więcej multimediów przy coraz większej przepustowości sieci. Problem ten zaostrzyła pandemia COVID-19. Pogląd o nieszkodliwości technologii informacyjnych i komunikacyjnych jako czystych i nieszkodliwych dla środowiska został podważony już w 2012 roku (a więc na długo przed gwałtownym wzrostem popularności streamingu filmowego) przez Richarda Maxwella i Toby’ego Millera. Wykazali oni, że fizyczna rzeczywistość ich wytwarzania, konsumpcji i wyrzucania powiązana jest $\mathrm{z}$ wykorzystaniem toksycznych materiałów, tworzeniem niebezpiecznych odpadów i szkodliwymi dla zdrowia warunkami pracy [Maxwell, Miller 2012]. Niska świadomość ekologicznych kosztów życia i pracy w otoczeniu cyfrowym jest bardzo dużym wyzwaniem i problemem, co zostało pokazane w monografii Media and the ecological crisis, w kompleksowy sposób ujmującej kwestię złożonego wkładu mediów w obecny kryzys ekologiczny [Maxwell, Raundalen, Lager Vestberg 2017, s. 2-5]. Indywidualne wybory i dobre praktyki nie wystarczą, aby rozwiązać problem kosztów środowiskowych wiążących się z mediami strumieniowymi. Prawdziwie skuteczne działania w tym kierunku muszą być szeroko zakrojone, podejmowane zarówno przez branże, jak i rządy poszczególnych państw. Pierwszym krokiem do wspólnego działania musi być jednak uwidocznienie - w szerszym dyskursie publicznym - kosztów, jakie niosą ze sobą eksploatacja energii i korzystanie z mediów. 
Badacze eksplorujący temat zrównoważonej produkcji filmowej już od kilku lat podają przykłady praktycznych rozwiązań, możliwych do zastosowania w produkcji filmowej. Jonathan Victory [2014, s. 53-33] już kilka lat temu postulował konieczność i uzasadniał potrzebę wprowadzenia do ekipy produkcyjnej ekomenedżera czy też specjalisty do spraw zrównoważonej produkcji. Jeśli producenci będą zatrudniać osobę, której zadaniem będzie nadzorowanie inicjatyw związanych z zieloną produkcją filmową, wówczas dobre praktyki łatwiej się upowszechnią. Chociaż istnieją przesłanki, że taki specjalista może stać się przydatną częścią zespołu filmowego, branża filmowa może być niechętna wprowadzaniu nowego członka do ekipy filmowej, obawiając się, iż zakłóci on ustaloną dynamikę planu filmowego. Jak podkreśla Victory [2014], zrównoważenie środowiskowe i efektywne wykorzystanie zasobów należy uznać za integralną część produkcji filmowej. Inicjatywy te są najbardziej skuteczne, gdy stoją za nimi ponadprzeciętne talenty i liderzy. Jednakże sama idea społecznej odpowiedzialności biznesu nie wystarcza do motywacji ekip. Należy wykazać pewną korzyść finansową wynikającą z ekologicznych praktyk - czy to poprzez realne oszczędności (które są możliwe do osiągnięcia), czy poprzez dostęp do dotacji, czy w inny sposób. Praktyki zrównoważonego rozwoju są możliwe niezależnie od wielkości produkcji, ale najbardziej skuteczne są wtedy, gdy są dobrze zorganizowane, nadzorowane przez właściwe osoby i przestrzegane przez zmotywowaną załogę. Wśród uniwersalnych narzędzi przyspieszających wdrożenie idei równowagi ekologicznej Victory wymienia m.in.: międzynarodową promocję idei zrównoważonej produkcji, koordynację prac departamentów czy komórek instytucji z zakresu filmu i telewizji zajmujących się tym obszarem, uzależnienie finansowania od raportowania, przekazywanie wybranym pracownikom branży filmowej roli ekologicznego supervisera czy wreszcie zorganizowany lobbing w celu zainicjowania inwestycji w technologie ekologiczne [Victory 2015, s. 66].

Ludovica Chiarini i Nadia Khedachi [2017, s. 8-35] wskazują na fakt, że branże, których funkcjonowanie oparte jest na realizacji określonych przedsięwzięć czy projektów, takie jak branża filmowa, charakteryzują się płynnymi przepływami pracy i niestandardowymi procedurami. Nie odczuwają one jeszcze negatywnych reakcji konsumentów wrażliwych na kwestie ochrony środowiska, niemniej jednak coraz częściej dostrzega się dążność do raportowania podejmowanych przez branżę działań na rzecz środowiska, ze względu na zwiększoną świadomość zmian klimatycznych i potrzebę ewolucji z podejścia biznesowego w kierunku zrównoważonego rozwoju. Presja pochodzi ze strony interesariuszy zarówno wewnętrznych, jak i zewnętrznych. Jak zauważają autorki [Chiarini, Khedachi 2017, s. 47], mimo dużego potencjału inicjatywy raportowania w branży filmowej są wciąż nieliczne i żadna z nich nie przyczyniła się jeszcze do stworzenia zharmonizowanych ram obowiązujących wszystkie podmioty. Branża filmowa wciąż jest niezwykle sceptyczna, jeśli chodzi o raportowanie w zakresie zielonej produkcji, zdarza się bowiem wśród jej przedstawicieli pogląd, że twórczy charakter branży nie powinien być osłabiany 
przez tego typu praktyki. Kolejną przeszkodą jest niedostateczne przywiązywanie wagi do tematu komunikacji w zakresie praktyk zrównoważonego rozwoju przez władze państwowe, polityków i instytucje publiczne. To bezpośrednio przekłada się na niechęć do ustanawiania premiujących te praktyki systemów finansowych.

\section{Lagiraniczne opracowania na temat dobrych praktyk w branży filmowej}

Liderem wdrażania zielonych rozwiązań w sektorze audiowizualnym jest Wielka Brytania. W raporcie British Film Institute [BFI 2020] opublikowanym w marcu 2020 roku zaznacza się potrzebę wprowadzenia radykalnych zmian, aby wypełnić zobowiązania Wielkiej Brytanii w zakresie redukcji emisji dwutlenku węgla. Podstawowe rekomendacje BFI [Albert 2020, s. 13-51] dotyczą takich aspektów produkowania filmów, jak:

- ponowne użycie materiałów budowlanych i scenograficznych, odpowiedzialny zakup nowych, efektywne wykorzystanie materiałów;

- zmniejszenie zapotrzebowania na energię i wodę, zrównoważenie źródeł energii;

- inteligentne gospodarowanie budynkami i obiektami studyjnymi, skonsolidowanie ruchu, planowanie komunikacji;

- usprawnienie narzędzi współpracy, wirtualne planowanie i wprowadzanie wspólnej infrastruktury.

Tabela 1 przedstawia przykładowe rozwiązania zastosowane w filmach brytyjskich i produkowanych z udziałem Wielkiej Brytanii.

Tabela 1. Przykłady praktyk zrównoważonej produkcji filmowej w Wielkiej Brytanii

\begin{tabular}{|l|l|}
\hline \multicolumn{1}{|c|}{ Tytuł filmu } & \multicolumn{1}{|c|}{ Wybrane praktyki } \\
\hline \multirow{5}{*}{ Yesterday (2019) } & $\begin{array}{l}\text { Program recyklingu i kompostowania } \\
\text { Dokumenty cyfrowe } \\
\text { Papier z recyklingu } \\
\text { Wskazówki dla ekipy na planach pracy } \\
\text { Motywacja ekipy } \\
\text { Butelki na wodę wielokrotnego użytku } \\
\text { Oświetlenie LED } \\
\text { Zakaz pracy samochodów na biegu jałowym } \\
\text { Korzystanie z transportu publicznego } \\
\text { Komunikaty środowiskowe wyświetlane na ekranie } \\
\text { Przekazywanie żywności (nieskonsumowanej w ramach } \\
\text { cateringu), rekwizytów, dekoracji oraz kostiumów } \\
\text { organizacjom non profit }\end{array}$ \\
\hline
\end{tabular}




\begin{tabular}{|l|l|}
\hline & Kształcenie załogi \\
& Program zagospodarowania odpadów, recyklingu, \\
& kompostowania, eliminacja odpadów \\
Mamma Mia! Here We Go Again & Zasilanie grzejników biopaliwem \\
(2018) & Butelki na wodę wielokrotnego użytku \\
& Papier z recyklingu \\
& Swiatła LED \\
& Przekazywanie żywności (nadwyżki cateringu), odzieży \\
& i innych artykułów organizacjom charytatywnym \\
\hline & Butelki na wodę wielokrotnego użytku \\
& Papier z recyklingu, oszczędzanie papieru, druk na \\
& życzenie \\
& Niestandardowe oznakowanie pojemników do \\
& recyklingu (system dinozaurów) \\
& Pojazdy hybrydowe \\
& 75\% oświetlenia LED \\
& Przyczynienie się produkcji do powstania programu \\
& darowizn żywności zbędnej na planie \\
\hline
\end{tabular}

Źródło: opracowanie własne na podstawie BFI 2020

Jakkolwiek w brytyjskim przemyśle filmowym widać zmianę postaw wobec zrównoważonego rozwoju i ochrony środowiska, brakuje koordynacji strategicznej na szerszą skalę. Inicjatywy te zyskują coraz większe uznanie, nadal jednak są drugorzędne wobec presji komercyjnej. Czołowe amerykańskie studia filmowe, które kręcą filmy w Wielkiej Brytanii, używają też alternatywnego systemu obliczania emisji dwutlenku węgla i innego systemu certyfikacji zrównoważonego rozwoju firmowanego przez Production Guild of America [BFI 2020].

Inny najnowszy raport organizacji Sustainable Production Alliance kładzie nacisk przede wszystkim na oszczędności ekologiczne w zakresie stosowania paliw i przejścia na rozwiązania w zakresie energii odnawialnej [Sustainable Production Alliance 2021]. Paliwa używa się do transportu i do agregatorów prądotwórczych potrzebnych do zasilania urządzeń na planie filmowym. Wspomniana organizacja rekomenduje wypożyczanie samochodów elektrycznych i hybrydowych, stosowanie paliw zrównoważonych oraz korzystanie z sieci elektrycznej zamiast z kosztownych ekologicznie agregatów. SPA widzi szansę w postępujących zmianach technologicznych w produkcji tego typu urządzeń, wyposażanych w specjalne nowoczesne baterie i systemy solarne. Ograniczenia w istniejącej infrastrukturze, takie jak brak dostępu do zasilania sieciowego lub stacji ładowania, stwarzają wyzwania dla produkcji filmowej.

W 2020 roku CineRegio, organizacja skupiająca regionalne fundusze filmowe w Europie, przygotowała manifest systemowego i instytucjonalnego wspierania ekologicznej kinematografii [Cine Regio 2020, s. 3-5]. Sygnatariusze porozumienia zwrócili uwagę na finansowy aspekt zagadnienia. Rozwój dobrych praktyk 
powstrzymuje obawa o zwiększenie kosztów produkcji i o możliwości uzyskania rekompensaty z tego tytułu od sektora publicznego. W rzeczywistości zielona produkcja filmowa niekoniecznie musi generować wyższe koszty. Jeśli jednak pojawią się wydatki ponadbudżetowe, powinny zostać kosztami kwalifikowalnymi w finansowaniu publicznym. CineRegio deklaruje, że będzie promować zrównoważone praktyki i zabiegać o to, by były one osiągalne dla branży audiowizualnej i instytucji ją finansujących. Porozumienie jest sygnowane m.in. przez Łódź Film Commission, a rekomendacje CineRegio już są stopniowo wprowadzane we wspieranych przez miasto produkcjach filmowych.

\section{Rozwój zrównoważonej produkcji filmowej w Polsce}

Na polskim gruncie pionierskie praktyki zrównoważonej produkcji realizowane są na podstawie powszechnie stosowanych zasad prowadzenia produkcji w harmonii ze środowiskiem, a także reguły zwanej 7R (reduce - ograniczaj, redukuj, reuse użyj ponownie, wykorzystaj, recycle - segreguj, repair - napraw, renew - odnawiaj, rethink - przemyśl na nowo, rot - kompostuj) [Zero Waste International Alliance]. Wdrażanie idei zrównoważonego rozwoju w produkcji audiowizualnej znajduje się obecnie na etapie wstępnym. Pierwsze widoczne i nagłośnione próby szerszego i świadomego zaimplementowania dobrych praktyk $w$ tym zakresie datuje się na lata 2019-2020. Przebiegają one w sposób dwutorowy. Z jednej strony problemem zrównoważonej produkcji zajęły się niektóre instytucje działające w sferze kinematografii, z drugiej - widoczne są indywidualne próby podejmowane przez producentów i twórców podczas realizacji konkretnych projektów.

Krajowa Izba Producentów Audiowizualnych (KIPA) oraz Łódź Film Commission i Regionalny Fundusz Filmowy w Łodzi, działające w ramach instytucji EC1 Łódź - Miasto Kultury, stworzyły pierwsze kodeksy dobrych praktyk oraz zorganizowały szkolenia i warsztaty na temat zielonej produkcji filmowej. Łódzki Fundusz Filmowy jest pierwszym polskim funduszem filmowym, który wprowadził do dokumentacji wnioskowej dla ubiegających się o dofinansowanie produkcji filmowej wartości liczbowe odnoszące się do zrównoważonej produkcji oraz zachęty do raportowania inicjatyw w tym zakresie. Przygotował także „kodeks” praktycznych rozwiązań i zastosowań idei zrównoważonego rozwoju w kontekście produkcji filmowej [ŁFC 2020]. Od 2019 roku KIPA zachęca producentów filmów do podjęcia się funkcji ambasadora zielonej produkcji w Polsce, organizuje spotkania i webinaria, przygotowała też broszurę informacyjną [KIPA 2020]. System rekomendacji przygotowanych na potrzeby polskiego rynku uwzględnia jego znaczne ograniczenia budżetowe, konserwatyzm środowiska, powolne tempo przyswajania zmian oraz specyfikę grupy polskich producentów filmowych, wśród których coraz większe znaczenie mają młode firmy oparte na zarządzaniu wiedzą. Tabela 2 przedstawia 
zestawienie dobrych praktyk proponowanych przez Krajową Izbę Producentów Audiowizualnych polskim producentom.

Tabela 2. Katalog „zielonych” praktyk w zakresie produkcji filmowej rekomendowanych przez KIPA

\begin{tabular}{|c|c|}
\hline $\begin{array}{c}\text { Obszar } \\
\text { zaangażowania }\end{array}$ & Proponowane rozwiązania \\
\hline Lokacje & $\begin{array}{l}\text { Zmniejszenie liczby lokacji celem ograniczenia transportu } \\
\text { Lokacje najbliżej centrum produkcyjnego } \\
\text { Ustawianie kolejności zdjęć pod kątem ograniczenia transportu } \\
\text { Dogodny i bliski parking } \\
\text { Ekspertyza na temat terenu planowanych zdjęć pod kątem istotnych } \\
\text { dla niego lokacji }\end{array}$ \\
\hline Plan zdjęciowy & $\begin{array}{l}\text { Kosze do segregacji } \\
\text { Wielorazowe naczynia, kubki, sztućce } \\
\text { Woda z kranu zamiast wody butelkowanej } \\
\text { Minimalizacja liczby odpadów } \\
\text { Wyłączanie nieużywanych sprzętów } \\
\text { Ograniczanie transportu w ciągu dnia na korzyść transportu } \\
\text { publicznego i rowerów }\end{array}$ \\
\hline Transport & $\begin{array}{l}\text { Hotel zamiast dojazdów } \\
\text { Wspólne podróżowanie (samochodami prywatnymi, taksówkami lub } \\
\text { środkami komunikacji publicznej) } \\
\text { Ograniczenie do minimum lotów, zwłaszcza krajowych } \\
\text { Korzystanie z firm transportowych z certyfikatami, flotą ekologiczną } \\
\text { itd. }\end{array}$ \\
\hline Scenografia & $\begin{array}{l}\text { Wypożyczenie/dzierżawa towarów i produktów potrzebnych do } \\
\text { budowy scenografii zamiast kupna nowych } \\
\text { Używanie materiałów przyjaznych środowisku } \\
\text { Recykling materiałów i korzystanie z materiałów używanych }\end{array}$ \\
\hline Catering & $\begin{array}{l}\text { Rezygnacja z jednorazowych opakowań } \\
\text { Wielorazowe naczynia i sztućce } \\
\text { Lokalni dostawcy, lokalne produkty (w miarę możliwości) } \\
\text { Dzień wegetariański }\end{array}$ \\
\hline
\end{tabular}




\begin{tabular}{|l|l|}
\hline \multirow{5}{*}{ Energia } & $\begin{array}{l}\text { Wymiana żarówek na żarówki LED w biurze i na planie } \\
\text { Rozwiązania, które zmniejszają liczbę lamp w pionie operatorskim } \\
\text { Wyłączanie urządzeń i ładowarek, z których się aktualnie nie korzysta } \\
\text { Podczas filmowania w plenerze w miarę możliwości korzystanie } \\
\text { z istniejących sieci i ograniczenie korzystania z generatorów prądu } \\
\text { Używanie akumulatorków (baterii wielokrotnego użytku) }\end{array}$ \\
\hline Woda i ziemia & $\begin{array}{l}\text { Ekologiczne detergenty } \\
\text { Utylizacja chemikaliów }\end{array}$ \\
\hline Praca z ekipą & $\begin{array}{l}\text { Zatrudnienie „zielonego" kierownika produkcji/asystenta } \\
\text { Skorzystanie z zewnętrznych porad na etapie preprodukcji oraz } \\
\text { na planie, a także do oceny wpływu na środowisko na etapie } \\
\text { postprodukcji } \\
\text { Zielona produkcja jako cel całego zespołu }\end{array}$ \\
\hline Papier & $\begin{array}{l}\text { Zmniejszanie liczby scenariuszy, dokumentów, planów, druk } \\
\text { dwustronny } \\
\text { Dokumenty podatkowe (PIT) przekazywane drogą elektroniczną } \\
\text { Scenariusze na czytnikach elektronicznych }\end{array}$ \\
\hline Otoczenie & $\begin{array}{l}\text { Informowanie o green filmingu w materiałach promocyjnych, } \\
\text { komunikatach medialnych } \\
\text { Dzielenie się wiedzą z innymi producentami } \\
\text { Współpraca z organizacjami zajmującymi się ekologią } \\
\text { i zrównoważonym rozwojem }\end{array}$ \\
\hline Znome
\end{tabular}

Źródło: Opracowanie własne na podstawie KIPA 2020.

KIPA jest jednym z polskich podmiotów, którzy biorą udział w europejskim projekcie Green Screen, obok Łódź Film Commission, Mazovia Warsaw Film Commission, Podkarpackie Film Commission i Rzeszowskiej Agencji Rozwoju Regionalnego SA [Rzeszowska Agencja Rozwoju Regionalnego 2020]. Projekt ten ma pomóc w opracowaniu i wdrożeniu zrównoważonych metod i narzędzi realizacji produkcji filmowych, telewizyjnych i treści audiowizualnych. Specjalnie powołany przy KIPA zespół pracuje obecnie nad opracowaniem twardych finansowych rozwiązań, które zdaniem polskich specjalistów są niezbędne dla wdrożenia idei zrównoważonego rozwoju. Dlatego takie zachęty powinny znaleźć się przede wszystkim w programach dofinansowania produkcji filmowych Polskiego Instytutu Sztuki Filmowej i regionalnych funduszy filmowych.

Pandemia COVID-19 spowodowała, że wiele organizacji i festiwali filmowych zaczęło szukać ciekawych, przyszłościowych i zgodnych ze światowym trendem tematów debat. Kwestia zielonej produkcji filmowej poruszana była w 2020 roku m.in. na festiwalach w Gdyni i w Koszalinie, które podjęły dyskusję na temat „zielonej” kultury filmowej. Stała się też tematem cyklu artykułów w mediach Stowarzyszenia 
Filmowców Polskich [Bonikowska 2020a, b]. Paradoksalnie, pandemia zwróciła również uwagę na łatwość zastosowania części proekologicznych rozwiązań w ramach organizacji samych festiwali, takich jak: ograniczenia w liczbie druków ulotnych i pamiątek festiwalowych, oszczędności w transporcie i możliwości korzystania z transportu publicznego, rezygnacja z części przelotów gości festiwalowych. Jednocześnie organizatorzy festiwali zaczęli podnosić wspomnianą wyżej kwestię niewidzialnego wpływu streamingu na środowisko naturalne [Bonikowska 2020a, b].

Zainteresowanie tematyką zielonej produkcji rośnie; w 2021 roku zorganizowane były kolejne szkolenia dla branży filmowej i wykłady na ten temat. Analiza wypowiedzi producentów, kierowników produkcji i twórców pozwala na stworzenie obrazu pionierskich praktyk z zakresu zrównoważonej produkcji filmowej w polskim kontekście. Jak mówią pionierzy zielonej produkcji filmowej w Polsce, idea zrównoważonego rozwoju w produkcji filmowej dojrzewała od dłuższego czasu, zanim została wdrożona w praktyce [Wróblewska 2020]. Tomasz Morawski z całym pionem produkcyjnym (HAKA Films, Tarapaty 2) rozpoczął od prostych czynności biurowych, takich jak przejście na druk dwustronny i elektroniczne faktury. Ograniczono druk scenariuszy i planów pracy. Szybko zrezygnowano z używania plastiku w cateringu, wprowadzono naczynia papierowe i wielorazowe. Dzięki eliminacji plastiku i papieru oszczędzono na wywozie śmieci. Producenci rozmawiali z ekipą i starali się przekonać jej członków do działań redukujących zużycie materiałów i zasobów środowiska naturalnego. Podjęte środki nie okazały się znaczącym obciążeniem budżetowym, mimo iż producenci świadomie podjęli ryzyko. Zarówno Morawski, jak i producentka oraz kierowniczka produkcji Daria Maślona (Studio Munka SFP) przyznają, że reakcja ekipy na działania proekologiczne jest niemal zawsze pozytywna. Członkowie ekip, coraz częściej pracujący na planach międzynarodowych koprodukcji, obeznani są z nowymi trendami i praktykami w produkcji filmowej. Niekiedy szefowie pionów muszą jednak być skłonni do dostosowania swoich budżetów (i modyfikacji struktury kosztów) w taki sposób, aby przestawić się na rozwiązania proekologiczne, jak w przypadku debiutanckiego niskobudżetowego filmu Wiarołom Piotra Złotorowicza. Żeby jednak te rozwiązania były skuteczne, muszą równolegle iść za nimi wielokrotnie wspominane tu rozwiązania systemowe, instytucjonalne oraz finansowe, które powinny zaczynać się już na etapie wniosków o dofinansowanie, których zawartość jest kształtowana przez instytucje publiczne. Dodatkowo, podobnie jak za granicą, pandemia COVID-19 skomplikowała ten proces. Na początku epidemii, bezpośrednio po otwarciu planów zdjęciowych, czasowo powrócono do starych, mniej ekologicznych praktyk, z powodu obostrzeń higienicznych [Wróblewska 2020].

Paweł Kosun (Centrala Film, produkcja Lipstick on the Glass w reżyserii Kuby Czekaja) podkreśla [Wróblewska 2020], że wprowadzanie praktyk proekologicznych na planie filmowym odbywa się zazwyczaj małymi krokami, na przykład poprzez wymianę sztućców i ograniczenie śmieci. Wdrażanie tych rozwiązań zależy od 
charakteru produkcji. W dużym ośrodku, gdzie ekipa stacjonuje w jednym miejscu, jest to prostsze niż w przypadku ekipy często się przemieszczającej. Jeśli jednak nie zostaną wypracowane konkretne systemowe rozwiązania i zachęty, to te inicjatywy będą nadal podejmowane w ograniczonym zakresie - bardziej dla „uspokojenia sumienia" i z poczucia wewnętrznego obowiązku niż po to, by w spójny, całościowy sposób wdrażać zasady zrównoważonej produkcji filmowej. Trudno na przykład mówić o ograniczaniu zużycia energii, jeśli agregat prądotwórczy pracuje non stop 12 godzin. Implementacja zasad zrównoważonej produkcji filmowej jest możliwa, jeśli zastosuje się bardzo praktyczne rozwiązania, jak zapewnienie każdej produkcji możliwości sortowania odpadów na hali i podłączenia do prądu. Członkowie ekip filmowych znają już z codziennego życia zasady segregowania śmieci i zasady wspólnego transportu. Location manager Michał Korynek [Wróblewska 2020] szacuje na przykład, że dzięki prostym rozwiązaniom podczas trzech ostatnich produkcji, przy których pracował, objętość śmieci zmniejszyła się od 30 do 50\%. Ekipa sequelu Mamma Mia! niemal całkowicie wyeliminowała wyrzucanie odpadów [BFI 2020, s. 82]. Podobnie jak w krajach Europy Zachodniej, tak i w Polsce źródłem zanieczyszczeń są agregaty, przetwarzające ogromne ilości paliwa. Jeszcze do niedawna procedury rozpatrywania wniosków ekip filmowych o podłączenie do sieci elektrycznej były zbyt długie, by mogły być stosowane przez produkcję filmową. Ostatnio jednak u dostawców energii elektrycznej pojawiły się szybsze (nawet 48-godzinne) drogi uzyskania pozwoleń. Gdyby takie systemy stały się normą, agregat byłby wyłącznie zabezpieczeniem, a nie podstawą $\mathrm{w}$ trakcie nagrywania poza studiem filmowym [Wróblewska 2020].

Nie wszystkie punkty z zasady 7R da się przełożyć na produkcję filmową. Tylko w nielicznych wypadkach można sobie wyobrazić ponowne wykorzystanie dekoracji. Czasem zresztą może ona nie przetrwać demontażu, a „odzyskiwalne” materiały drewniane są połączone ze środkami chemicznymi, co utrudnia recykling. Obiecującym terenem działań na rzecz środowiska jest natomiast rekomendowana przez polskie i zagraniczne instytucje organizacja pracy w biurze i systemu komunikacji między pracownikami. Oprócz zmniejszenia zużycia papieru można ograniczyć niepotrzebne, pozbawione ważnych treści maile, wielkie załączniki i pliki, powodujące obciążenie serwerów. Ten koszt ekologiczny jest równie ważny, choć mniej widoczny i odsunięty w czasie.

Poważnym wyzwaniem jest motywacja ekip filmowych do proekologicznego działania. W przypadku prostych praktyk widać z gruntu pozytywne postawy, problemy zaczynają się w momencie, gdy zmiana przyzwyczajeń wymaga uwagi i pracy. Stąd podczas debaty na temat zielonej produkcji filmowej goście FPFF w Gdyni podkreślali siłę motywacji i znaczenie mechanizmu naśladownictwa dobrych praktyk. Reżyserka Jagoda Szelc (Wieża. Jasny dzień, Monument) [FPFF 2020] zwróciła uwagę, że zielona produkcja filmowa powinna zaczynać się już na etapie scenariusza. Autorzy scenariuszy i reżyserzy często szukają atrakcyjnych lokacji dla 
realizacji danego dzieła filmowego, „zasłaniając” brak przemyślanej koncepcji artystycznej dzieła filmowego pięknymi pejzażami, bogactwem scenografii czy efektami specjalnymi. Zamiast znaleźć rozwiązanie dramaturgiczne w scenariuszu, kładzie się nacisk na dekoracyjną inscenizację czy jeździ się po kraju w poszukiwaniu robiącej wrażenie lokacji. Ślad węglowy produkcji filmowej można też, zdaniem reżyserki, ograniczyć dzięki dobremu przygotowaniu produkcji, a jednocześnie skutecznej komunikacji wewnątrz grupy zdjęciowej. Spotkanie na etapie preprodukcyjnym i precyzyjne przygotowanie pracy pozwala na tworzenie dobrze współpracujących zespołów i wydajną pracę, oszczędza stres oraz skraca czas pracy. Koszty improwizacji ponosi bowiem środowisko naturalne.

Według aktora Bartosza Bieleni (Prime Time, Boże Ciało) [FPFF 2020] w branży filmowej pokutują pewne stare praktyki, które można i należy zmienić, jeśli produkcja filmowa ma się stać bardziej „zielona”. Należy się zastanowić, czy aktorzy powinni nadal korzystać ze specjalnego traktowania, osobnego kampera i transportu. Osoby o popularnych nazwiskach powinny wykorzystać potencjał gwiazdorski dla budowania świadomości ekologicznej zarówno w branży filmowej, jak i w społeczeństwie. Także w wąskim zakresie odpowiedzialności w pracy na planie. Indywidualna praca członka ekipy wpływa na pozostałych jej uczestników. Koszty błędów wynikających z nieprzygotowania są ogromne, co widać na przykładzie dubli. Istotne jest przy tym stosowanie własnego kodeksu etycznego, który może pozytywnie oddziaływać na innych. Aktor może mieć wpływ na zakup kostiumów ze sklepów z używaną odzieżą, na wybór środków transportu, na wybór diety wegetariańskiej na planie. Jeśli ma odpowiednią pozycję, może również zagwarantować sobie pewne rozwiązania w umowie. Producent Stanisław Zaborowski (Silver Frame) [FPFF 2020] uważa ponadto, że istotne są działania edukacyjne i mądre wybieranie podwykonawców. Zasadne będzie bowiem zapytanie scenografa o możliwości ponownego użycia materiałów jeszcze przed podjęciem decyzji o zatrudnieniu.

Przytoczone powyżej inicjatywy zarówno instytucji (m.in. KIPA, Łódź Film Commisssion), jak i twórców oraz producentów składają się na obraz środowiska, które ideę zrównoważonego rozwoju w kinematografii wdraża indywidualnie, oddolnie i z własnej inicjatywy. Są to zespoły niewielkie, które podejmują określone działania ze względu na własne przekonania lub też dlatego, że na bieżąco obserwują trendy w światowej kinematografii, są częścią organizacji europejskich i realizują ich cele. Producenci - pionierzy zielonej produkcji filmowej - w ten sposób wypracowują pozycję społecznego lidera. Dopóki jednak inicjatywy te nie będą wyraźnie wspierane i promowane przez centralne instytucje, takie jak PISF, spółki telewizyjne oraz regionalne instytucje filmowe, będą traktowane przez branżę jako rodzaj środowiskowego ekscesu, a nie norma.

Proekologiczne działania wychodzą na razie niemal wyłącznie od producentów z grupy zwanej know-how [Majer, Orankiewicz, Wróblewska 2019, s. 194-195]. Określani niegdyś w branży „młodymi producentami”, są specjalistami, którzy zaczynali 
karierę na początku XXI wieku, po wprowadzeniu w życie Ustawy o kinematografii i po wejściu Polski do UE. Ich działalność oparta jest na kompetencjach, wiedzy oraz sieci kontaktów zdobywanych w kraju i za granicą.

Wymienione w niniejszym tekście filmy to produkcje autorskie, średnio- lub niskobudżetowe. Producenci nie otrzymują zachęt finansowych ani żadnych innych, które by ich motywowały do bardziej ekologicznej produkcji filmowej. Dodatkowo niska świadomość ekologicznych kosztów produkcji w społeczeństwie tworzy wokół branży filmowej komfortową osłonę, dzięki której nie musi ona, jak dotąd, tłumaczyć się ze swoich działań opinii publicznej, znacznie bardziej wyczulonej na takie kwestie związane z kinematografią, jak udział finansowania publicznego $\mathrm{w}$ filmach, zarobki gwiazd czy problem nierównego traktowania kobiet i molestowania seksualnego.

Z tego też względu zaangażowanie producentów we wdrażanie idei zrównoważonej produkcji ma na razie charakter idealistyczny, pionierski. Można je interpretować w kontekście społecznej odpowiedzialności biznesu. Jak zauważa Jadwiga Adamczyk, zarządzanie nowoczesnym przedsiębiorstwem musi dziś uwzględniać bardzo ważne cele ochrony środowiska. Ochrona środowiska nie jest bowiem celem samym w sobie, jest nim jakość życia, na którą wpływają warunki zdrowotne, czystość środowiska, dostępność zasobów naturalnych, piękno krajobrazu. Jeśli uznamy jakość życia za najwyższe dobro, musimy uwzględnić ochronę środowiska jako jeden z celów społecznych działalności przedsiębiorców. Świadomość społeczna rośnie, dostęp do informacji jest coraz łatwiejszy, ujawniane są zachowania nieetyczne [Adamczyk 2009, s. 17-18]. Proekologiczne podejście w kinematografii ma więc charakter polityki zorientowanej na przyszłość, zakładającej cele, które w dyskursie społecznym dopiero zostaną sformułowane.

\section{Podsumowanie}

Pionierzy zielonej produkcji filmowej kierują się w swych działaniach troską o wspólne dobro, jakim jest środowisko naturalne i zrównoważone wykorzystanie zasobów. Polskie praktyki w tej materii są jednak bardzo skromne. Wdraża się rozwiązania funkcjonalne, które nie zakłócają poważnie kultury planu filmowego (energooszczędne oświetlenie, rozwiązania transportowe, ograniczenie druku, rezygnacja z plastiku w cateringu). Największy szkodnik - generator prądu - będzie powszechnie stosowany w produkcji filmowej, dopóki spółki energetyczne nie wdrożą szybkich ścieżek podłączenia produkcji filmowych do sieci. Jednak nawet najbardziej staranna polityka proekologiczna rozwiniętych kinematografii nie wyeliminuje niszczącego wpływu produkcji filmowej na środowisko, a jedynie zmniejszy go. Znacznie łatwiej wprowadzić dobre praktyki do produkcji filmów nisko- lub średniobudżetowych, z ograniczoną inscenizacją, ze stosunkowo niewielką liczbą wykorzystanych lokacji, ze średniej wielkości kampanią reklamową. Tymczasem kluczowe obecnie pola 
eksploatacji filmu, jak kino czy VOD, zdominowane są przez produkcje z obszaru globalnego Hollywood. Produkcja filmów i seriali o ogromnych budżetach wiąże się nie tylko z rozmachem inscenizacyjnym czy angażowaniem gigantycznych ekip, ale też z agresywną kampanią marketingową, opartą na reklamie (także zewnętrznej) czy sprzedaży powiązanych produktów. Dlatego tak istotne w tym dyskursie są sygnały i rozwiązania, które płyną z USA i z Wielkiej Brytanii.

Pandemia COVID-19 w moim przekonaniu spowolniła procesy wdrażania praktyk proekologicznych. Producenci polskich filmów i seriali narzucili sobie ścisłe standardy pracy na planach filmowych, co wiązało się z wyższymi kosztami produkcji i z wyzwaniami organizacyjnymi. W tej sytuacji idea green filming chwilowo straciła na popularności, choć nie na ważności. Należy mieć nadzieję, iż jest to jedynie sytuacja czasowa, gdyż obserwacje poczynione przeze mnie na planach zdjęciowych w 2021 roku wykazały, że pewne dobre praktyki zdążyły już zakorzenić się $\mathrm{w}$ praktyce produkcyjnej. Widać tendencję do rezygnowania z plastiku, przyjęła się ona na tyle szybko, że mimo pandemii na planach zdjęciowych używa się najczęściej naczyń papierowych. Być może dlatego, że jest to rozwiązanie możliwe do zastosowania niezależnie od wielkości produkcji czy wysokości budżetu, a także w pewnym stopniu wymagane w ramach rozwiązań o charakterze ogólnokrajowym dotyczącym wszystkich branż. Wydaje się też, iż tematyka zielonej produkcji filmowej zagościła na dobre w programie ważnych krajowych imprez branżowych. Przykładowo, dyrekcja 46. Festiwalu Polskich Filmów Fabularnych w Gdyni zapowiedziała już rozbudowaną debatę w sekcji „Industria” w 2021 roku, co oznacza, że skromne webinaria z 2021 roku odbiły się szerokim echem.

Oprócz rozwiązań systemowych zasadne wydaje się wprowadzenie wymogu regularnego raportowania w zakresie implementacji rozwiązań ograniczających szkodliwy wpływ kinematografii na otoczenie. Raportowanie tego typu może być powiązane z systemem „zielonych” zachęt: jeśli podczas ubiegania się o dofinansowanie dana instytucja czy fundusz zdecydują się na przyznanie dodatkowych punktów dla zrównoważonych produkcji, mają pełne prawo domagać się informacji zwrotnej, która zresztą pozytywnie motywuje producenta. Jak zauważa Piotr Wachowiak, wiedza uzyskana dzięki raportowaniu może zostać wykorzystana do promocji idei zielonej produkcji filmowej i związanych z nią dobrych praktyk zarówno w bliższym, jak i dalszym otoczeniu [Wachowiak 2013, s. 134]. Poza analizą wąsko rozumianych efektów ekonomicznych coraz więcej przedsiębiorstw dokonuje pomiaru oddziaływania swojej działalności na sferę społeczną i ekologiczną. W ten sposób przedsiębiorstwo dostarcza informacji o wpływie działalności przedsiębiorstwa na środowisko społeczne i naturalne. W kontekście produkcji filmowej jest to szczególnie zasadne, biorąc pod uwagę charakter branży audiowizualnej, opartej na małych przedsiębiorstwach oraz pracownikach twórczych i pomocniczo-twórczych działających na zasadzie samozatrudnienia. To świat rozproszonych, małych i ruchliwych podmiotów. Łatwiej wdrażać nowe rozwiązania czy praktyki firmom 
działającym na zasadzie know-how, posiadającym niewielki, kreatywny zespół. Mała firma producencka będzie bardziej elastyczna i chętna do wewnętrznych zmian niż duża organizacja o formie spółki akcyjnej (np. publiczna stacja telewizyjna), z niezmiernie rozbudowanym aparatem zarządczym i ogromnym budżetem. Katarzyna Plebańczyk [2017, s. 308] dostrzega w realizacji idei zrównoważonego rozwoju siłę oddolnych, spontanicznych inicjatyw społecznych, które są zmienne i często wymykają się klasyfikacji. Dobre praktyki są opisywane i rozpowszechniane, dzięki czemu adaptują je kolejne grupy. Jednak tylko część z nich wchodzi do stałego systemu narzędzi zarządzania zrównoważonym rozwojem. I choć autorka pisze o małych grupach społecznych i społecznościach lokalnych, nie sposób nie zauważyć tu analogii z ekipą produkcyjną filmu.

Marcin Adamczak [2014, s. 137-138] widzi produkcję filmową jako płynny, zmienny, interakcyjny układ sieciowy czy wręcz kłącze - różnie kształtujące się przy każdej realizacji, a nawet przeobrażające się w trakcie procesu produkcyjnego. Zmieniające się praktyki mogą silnie oddziaływać na cały sektor. Immanentną cechą ekipy filmowej jest jej zmienny skład osobowy, a co za tym idzie - przenikanie do otoczenia zwyczajów, opowieści branżowych oraz (dobrych) praktyk. Z jednej strony perspektywy wdrażania zasad zielonej produkcji filmowej wydają się niepewne, bowiem bez wprowadzenia systemowych rozwiązań i wyraźnych działań ze strony sektora publicznego, w tym instytucji dofinansowujących produkcje filmowe, nowy trend może okazać się przejściową modą. Z drugiej natomiast - wiele zależy od oddolnych inicjatyw ludzi filmu. Zarysowuje się interesujący obszar badań praktyk produkcyjnych, które będą nadal zmieniały się i ewoluowały, choć kierunek ich zmian w kontekście zielonej produkcji filmowej pozostaje nieznany.

\section{Bibliografia}

\section{Monogirafie i artykuly}

Adamczak M. (2014), Obok ekranu. Perspektywa badań produkcyjnych a społeczne istnienie filmu, Poznań: Wydawnictwo Naukowe UAM.

Adamczyk J. (2009), Społeczna odpowiedzialność przedsiębiorstw, Warszawa: Polskie Wydawnictwo Ekonomiczne.

Bonikowska J. (2020a), Zielona produkcja filmowa. Zielone festiwale filmowe: Kraków, Gdynia, https://www.sfp.org.pl/wydarzenia,5,31154,2,1,Zielona-produkcja-filmowa-cz-III-Zielone-festiwale-filmowe-Krakow-Gdynia.html [odczyt: 20.04.2021].

Bonikowska J. (2020b), Zielona produkcja filmowa. Zielone festiwale filmowe: Transatlantyk, Nowe Horyzonty, https://www.sfp.org.pl/wydarzenia,5,31159,2,1,Zielona-produkcja-filmowa-cz-IV-Zielone-festiwale-filmowe-Transatlantyk-Nowe-Horyzonty.html [odczyt: 20.04.2021]. 
Chiarini L., Khedachi N. (2019), Sustainability reporting in project-based industries a European study with a focus on the motion picture industry, Malmö: Malmö University, Department of Urban Studies.

Ingram D. (2000), Green screen. Environmentalism and Hollywood cinema. Exeter: University of Exeter Press.

Majer A., Orankiewicz A., Wróblewska A. (2019), Pieniądze - Produkcja-Rynek. Finansowanie produkcji filmowej w Polsce, Łódź: Wydawnictwo PWSFTViT.

Marks U., Clark J., Livingston J., Oleksijczuk D., Hildebrand L., 2020, Streaming media's environmental impact, https://mediaenviron.org/section/1582-states-of-media-environment [odczyt: 20.04.2021].

Maxwell R., Miller T. (2012), Greening the media, Oxford: Oxford University Press.

Maxwell R., Raundalen J., Lager Vestberg N. (2017), Media and the ecological crisis, Londyn, Nowy Jork: Routledge.

Miller T. (2018), Greenwashing culture, London, New Jork: Routledge.

Özdemirci E. (2016) Greening the screen: An environmental challenge, „Humanities”, 5(2), 35, doi: $10.3390 / \mathrm{h} 5020035$.

Pabian A. (2017), Zrównoważone przedsiębiorstwo jako rezultat zarządzania strategicznego, [w:] A. Sopińska, P. Wachowiak (red.), Wyzwania współczesnego zarządzania strategicznego, Warszawa: Oficyna Wydawnicza SGH, s. 363-376.

Plebańczyk K. (2017), Kultura i zrównoważony rozwój - wykorzystanie narzędzi partycypacji zaangażowanej, „Zarządzanie w Kulturze”, nr 18, s. 307-325.

Victory J. (2014), Green shoots: The role of the eco-manager in sustainable film production, Staffordshire: Staffordshire University, s. 54-68.

Victory J. (2015), Green shoots: environmental sustainability and contemporary film production, "Studies in Arts and Humanities”, t. I, nr 1, s. 54-68.

Wachowiak P. (2013), Wrażliwość społeczna przedsiębiorstwa. Analiza i pomiar, Warszawa: Oficyna Wydawnicza Szkoła Główna Handlowa.

Wróblewska A. (2020), Zielona produkcja filmowa (cz. II). Zostaje po nas węglowy ślad, https:// www.sfp.org.pl/wydarzenia,5,31126,2,1,Zielona-produkcja-filmowa-cz-II-Zostaje-po-nas-weglowy-slad.html [odczyt: 20.04.2021].

\section{Dokumenty, raporty, strony WWW}

Albert (2020), A screen New Deal: a route map to sustainable film production.

BFI - British Film Institute, Bigger Picture Research (2020), Green matters. Environmental sustainability and film production: an overview of current practice.

CineRegio (2020), GREEN REPORT 2020 on sustainability in the European regions.

FPFF - Festiwal Polskich Filmów Fabularnych w Gdyni, Sustainable Film Production in Poland, https://www.youtube.com/watch?v=7inxPGZk_RM\&t=2205s, [odczyt: 31.08.2021]. 
Green Filming w Łodzi, http://lodzfilmcommission.pl/aktualnosci/green-filming-w-lodzi [odczyt: 14.03.2021].

ŁFC - Łódź Film Commission (2020), Zrównoważona produkcja filmowa. Wytyczne dot. green filmingu dla producentów filmowych realizujacych zdjęcia i/lub postprodukcje na terenie Łodzi/województwa łódzkiego.

KIPA - Krajowa Izba Producentów Audiowizualnych (2020), Green filming. Produkcja filmowa i telewizyjna przyjazna dla środowiska.

Rzeszowska Agencja Rozwoju Regionalnego (2020), Green Screen, https://rarr.rzeszow.pl/projekty/green-screen/ [odczyt: 14.03.2021].

Sustainable Production Alliance (2021), Carbon emissions of film and television production.

UCLA - University of California Los Angeles Institute of the Environment (2006), Sustainability in the motion picture industry.

Zero Waste International Alliance, https://zwia.org/zwh/ [odczyt: 1.09.2021]. 